\title{
THE EFFECT OF ADHESIVE PAPER WASTE WEIGHT PERCENTAGE IN BIOBRIQUET DERIVED FROM CASSAVA SKIN WASTE
}

\author{
ANeKa Firdaus ${ }^{1 *}$, Aditha Verdian PANAe ${ }^{2}$ \\ ${ }^{1}$ Department of Mechanical Engineering, Faculty of Engineering, Universitas Sriwijaya, Indralaya, \\ 30662, Sumatera Selatan, Indonesia \\ ${ }^{2}$ OKI Pulp and Paper Mills-Sinarmas Group, Indralaya, 30662, Sumatera Selatan, Indonesia \\ *Corresponding author: anekafirdaus@unsri.ac.id
}

(Received: 2 October 2020; Accepted: 17 November 2020; Published on-line: 30 November 2020)

\begin{abstract}
Cassava skin waste is waste originating from cassava plants from tapioca flour factories or cassava processed product factories. Indonesia is one of the biggest countries that produces cassava. The number of cassava processing industries in Indonesia is large so that a positive correlation can be drawn that the high amount of cassava processed will produce more cassava skin waste. Based on the results of tests conducted, the higher the composition of the Each cassava can produce 10-15\% of cassava skin waste. Cassava skin waste is directly removed, can cause buildup that results in environmental damage. Cassava skin waste is obtained from local farmers, where on average each cassava produces 10-15\% of waste. In general, this waste is not used and just thrown away. This research was conducted with the main ingredients of cassava peel waste and adhesive made from used paper. The composition of the mixture of cassava peel and used paper varies, where the percentage by weight of the adhesive starts from $7.0 \%$ to $10 \%$ with an increase in the composition every $0.5 \%$. Then the biobriquette carbonization process was carried out at a temperature of $400^{\circ}$ C. The biobriquette characterization was carried out based on ASTM standards to analyze water and ash, volatile matter and heating value. The results of the analysis on the composition of the lowest cassava bark had the highest heating value of $5888 \mathrm{cal} / \mathrm{gr}$ with the lowest water, ash and volatile matter content.
\end{abstract}

KEY WORDS: Bio-briquette, Cassava, Adhesive, Waste, Calorific

\section{INTRODUCTION}

The shortage of kerosene which was then followed by the difficulty of accessing liquid gas for household as a result program of the conversion of fuel for domestic use triggered the emergence of alternative energy sources, even renewable energy. This is stated in the Republic of Indonesia's Presidential Regulation No. 8 of 2019 concerning the National Energy Policy, which states that the government invites all parties and the people of Indonesia to succeed in the development of alternative energy sources to substitute fuel oil [1]. Renewable energy sources are needed for the supply of sustainable energy sources. This will be even better if it comes from waste, so that it can reduce production costs and reduce the negative effects of accumulation of waste on the environment.

Therefore, alternative fuels that are cheap and environmentally friendly are needed as a substitute for kerosene for small industries and households. One of the alternative energy is the use of briquettes from waste in the form of cassava peel. 
Cassava processing product industry and tapioca flour factory are one of the industries that are widely available in Indonesia. In the processing of cassava, the industry produces waste that is rarely used by people, namely cassava skin waste. According to the data, cassava production in Indonesia is very large because Indonesia is included as the fifth largest country in the world that produces cassava [2].

Cassava is a plant that is widely available in Indonesia. Cassava with the botanical name Manihot esculenta Crantz but better known by other names Manihot utilissima belongs to the kingdom Plantae, the Spermatophyta division, the Andiantian subdivision, the Dicotyledonae class, the Euphorbiaceae family, the genus Manihot with the species Crantz esculenta with various varieties [3]. According to the United Nations Industrial Development Organization (UNIDO), Indonesia is the second largest cassava-producing country in Asia after Thailand and ranks fifth in the world after Nigeria, Brazil, Thailand and Congo [2].

The abundance of cassava production, cassava processing industries emerged both small and large industries. Cassava processing industry produces solid waste in the form of cassava peels in large enough quantities and can trigger environmental pollution.With so many cassava, cassava processing industries emerged, both small and large industries. Cassava processing industry produces solid waste in the form of cassava peels in large enough quantities and can trigger environmental pollution.

Briquette is a solid fuel that can be used as an alternative energy source that has a certain form. The water content in briquettes is between 10-20\% by weight. Briquette size varies from 20 - 100 grams. The selection of the briquette process refers to market segments in order to achieve optimal economic, technical and environmental value. Packaging aims to obtain a quality fuel that can be used for all sectors as a substitute energy source.

Briquette manufacturing can produce biobriquette products with various results. This difference is seen from the type of raw material, the moisture content of the raw material the strength of pressure in compression [4]. The higher the water content, the weaker the strength of biobriquette. The higher the pressure applied, the strength of the briquettes will be greater and the heating value and density also increase, but the rate of combustion decreases [5].

Adhesives or binders are materials that can be used to bind briquette powder or charcoal from raw materials so that it can produce briquettes that are strong and not easily broken even if done in a low-pressure process. A good adhesive is certainly not dangerous when used and produced. The higher adhesive composition, the lower the heating value and the higher water content produced [6].

Biomass carbonization is a process to increase the heating value of biomass and produces clean combustion with little smoke. The results of carbonization are in the form of charcoal composed of carbon and black. Carbonization is a process to convert orgranic material into charcoal. the carbonization process will release flammable substances such as $\mathrm{CO}, \mathrm{CH}_{4}, \mathrm{H}_{2}$, formaldehyde, methane, formic and acetil acid as well as non-combustible substances such as $\mathrm{CO}_{2}, \mathrm{H}_{2} \mathrm{O}$ and liquid tar [7]. The gases released in this process have a high heating value and can be used to meet the heat requirements of the carbonization process.

The purpose of this research is to analyze the effect of adhesive paper waste weight percentage in biobriquet derived from cassava skin waste.

\section{METHOD AND MATERIALS}

In this study, the method used is an experimental method whose data is obtained by conducting experiments. Steps being taken to make briquettes include: Drying, separating, 
carbonizing, mixing and molding. This research was conducted and analyzed at the Coal Research Laboratory of the Ministry of Mines and Energy in Palembang.

Water content, reference standard: ASTM D 3173-11 (Standard Test Method for Moisture in the Analysis Sample of Coal and Coke). Moisture contained in briquettes can be expressed in two types: Free moisture, free moisture can be lost by evaporation, for example by air drying. The content of free moisture is very important in planning coal handling and Inherent moisture (water vapor bound) The content of inherent moisture can be determined by heating briquettes between temperatures $104-110^{\circ} \mathrm{C}$ for one hour.

Ash Content, reference standard: ASTM D 3174 - 11 (Standard Test Method of Ash in the Analysis Sample From Coal and Coke). All briquettes contain inorganic substances which can be determined as the amount of weight left when the briquettes are completely burned. This living substance is called ash. Briquette ash comes from clay, sand and various other mineral substances. Briquettes with high ash flowers are very unfavorable because they form crust. The content of flying substances.

Volatile matter, reference standard: ISO 562 - 2010 (Standard Test Method of Volatille Matter in Analysis of Samples of Coal and Coke). Flying matter consists of flammable gases such as hydrogen, carbon monoxide $(\mathrm{CO})$ and methane $\left(\mathrm{CH}_{4}\right)$, but sometimes there are also unburned gases such as $\mathrm{CO}_{2}$ and $\mathrm{H}_{2} \mathrm{O}$. Volatile matter is part of the briquette which will turn into volatile matter (product) if the briquette is heated without air at a temperature of approximately $950{ }^{\circ} \mathrm{C}$. For the level of $\pm 40 \%$ volatile matter on combustion will get a long flame and will give a lot of smoke. As for low volatile matter levels between 15-25\% more favored in use because the smoke produced is small.

Calorific value, reference standard: ASTM D 5865 - 11a (Standard Test Method for Gross Calorific Value of Coal and Coke). The calorific value is expressed as heating value, is an important parameter of a thermal coal. Gross calorific value is obtained by burning a briquette sample in a bomb calorimeter by returning the system to ambient temperament. Net calorific value is usually between $93-97 \%$ of the gross value and depends on the inherent moisture content and hydrogen content in the briquettes.

Solid Carbon, Reference Standard: ASTM D 3172-07a (Standard Practice for Proximate Analysis of Coal and Coke). Solid carbon or fixed carbon is carbon left over after the raw material is burned or after the flying substance is released. Determination of the amount of carbon anchored in a raw material can be determined directly by a hundred percent reduction in the amount of water, fly and ash content.

\section{RESULTS AND DISCUSSION}

The effect percentages of paper waste adhesives to the amount of moisture content (Inherent Moisture) can be seen in Figure 1. It is seen that the water content increased for each increasing in adhesive percentage. This is because, the higher the adhesive composition used, more water required to produce pulp. The increasing amount of water mixture on the adhesive, can affect the moisture content of the briquettes. In other words, the higher the composition of the waste paper adhesive used, the higher the moisture content value of a briquette.

In Figure 2. depict the content composition of the waste paper adhesives to ash content. With the lowest value in the composition of $7 \%$ while the highest in the composition of $10 \%$. It can be seen that the ash content increases with each increase in the composition of the paper waste adhesive. The higher the adhesive composition, the higher the ash content in the briquettes. 
This happens because the higher the content of paper in a briquette, the more the remaining parts that are not burned.

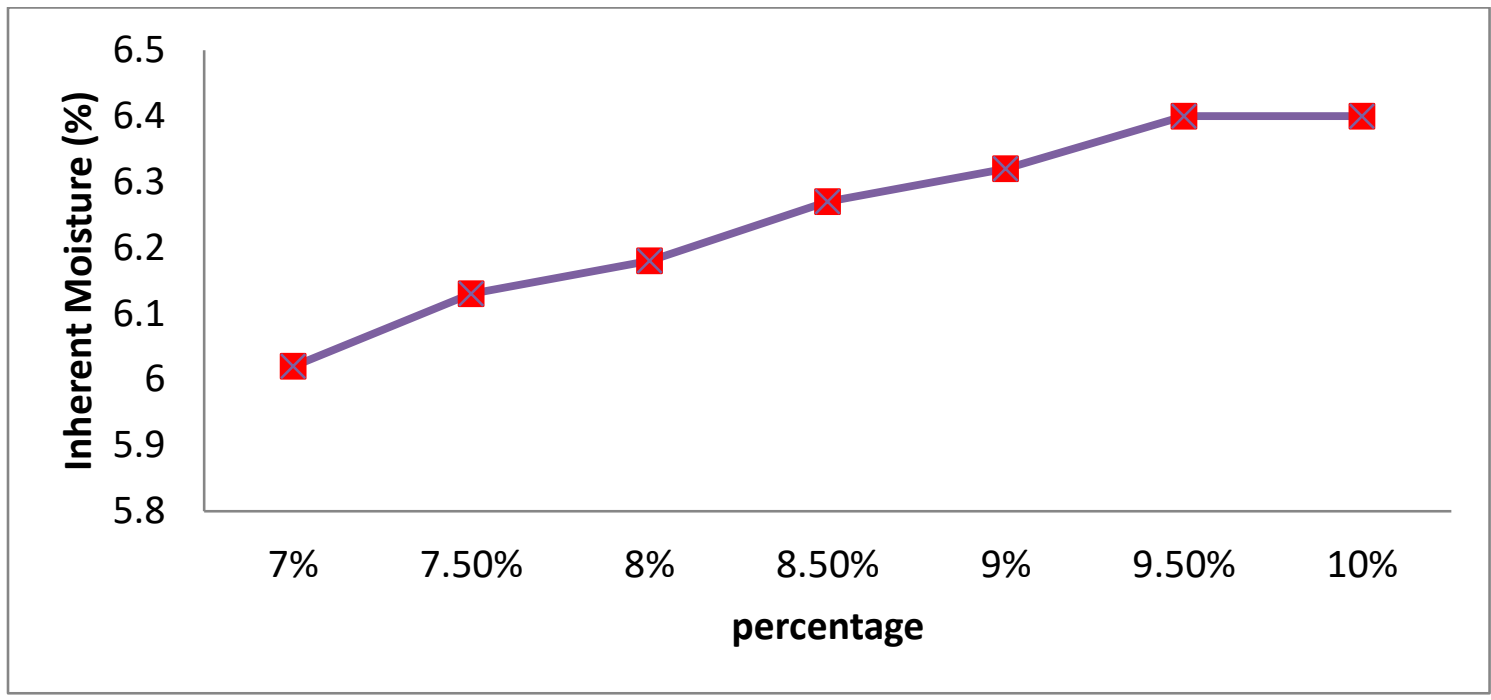

Fig. 1. The effect weight percentages of Paper Waste Adhesives to Moisture Content.

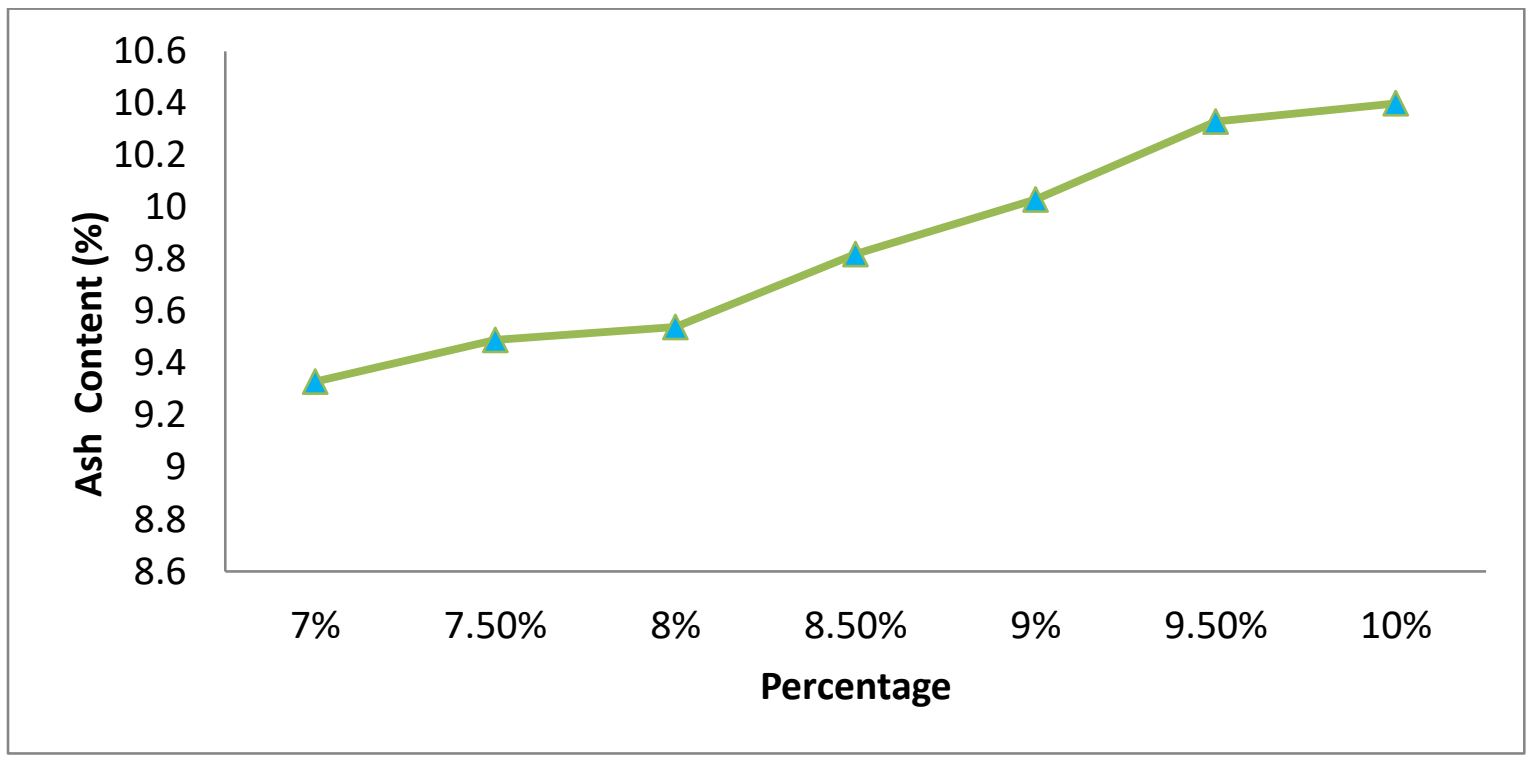

Fig. 2. The effect weight percentages of Waste Paper Adhesives To Ash Content.

Volatile Matter is a substance that can evaporate as a result of decomposition of compounds in charcoal other than water. The high vapor content in the briquette will cause more smoke when the briquette is ignited, this is caused by a reaction between carbon monoxide (CO) [8]. Based on the analysis data, the relationship between the composition of the adhesive and the volatile matter values in the briquettes can be seen in Figure 3: the picture shows that the lowest content of the flying substance is in the composition of the adhesive $7 \%$ and has an increase in each additional composition of the waste paper adhesive to the composition of $10 \%$ which has the highest content of the flying substance. This effect due to the influence of the large number of compositions of paper waste as an adhesive with the main material that has undergone a carbonization process. When the raw material undergoes a carbonization process, the flying substances contained in it will evaporate out of the material [9]. The less amount of paper waste 
contained in the briquettes, the lower the levels of flying substances, the higher the volatile content of the briquette, the briquette will be easier to catch fire and ignite [10].

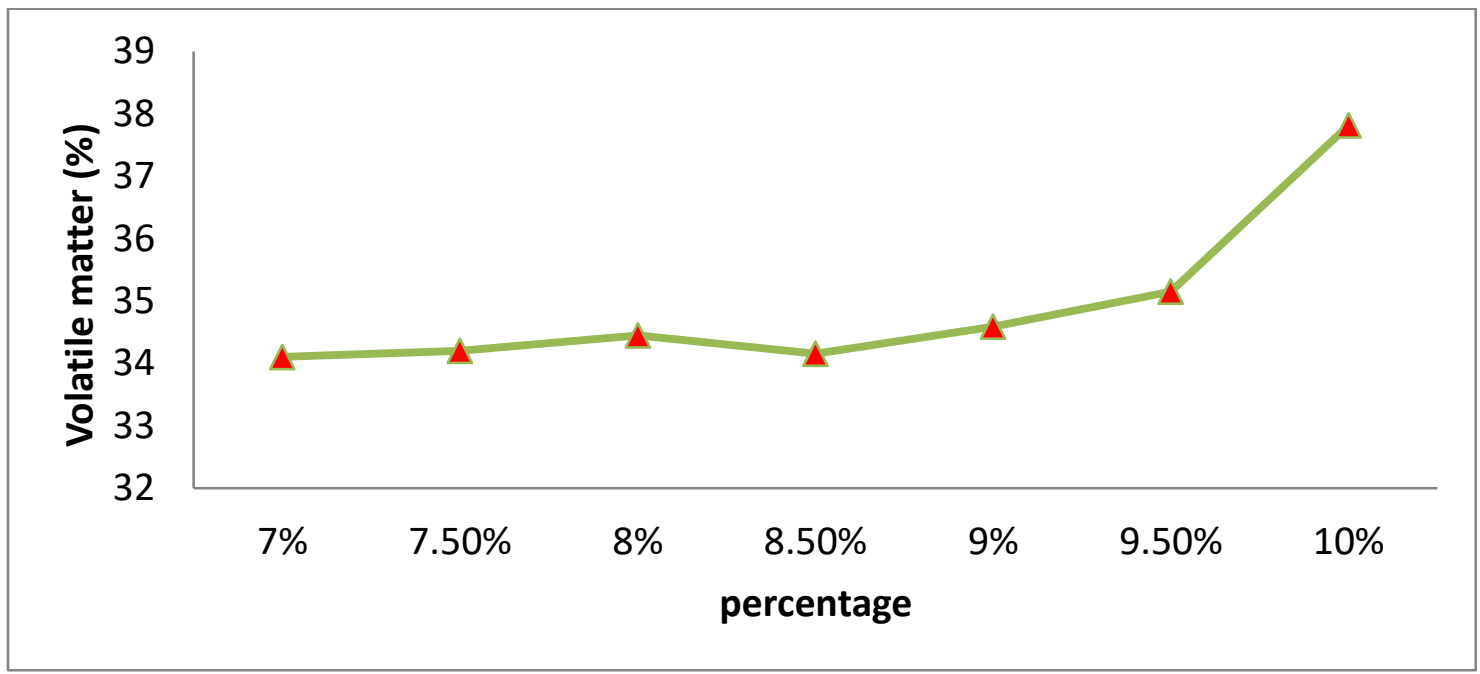

Fig. 3. The Relationship between weight percentages of Waste Paper Adhesives to volatile matter.

Solid carbon (fixed carbon) is carbon that bound in charcoal other than water, flying matter and ash content. Carbon content will be high if the ash content and levels of the briquette fly are low. The value of solid carbon in briquettes is influenced by the value of ash content and levels of flying matter. Solid carbon (fixed carbon) is an element (carbon) which is a material that can be burned by oxygen from the air. Solid carbon content can affect the burning time of briquettes [11].

Table 1. Fixed carbon content of the samples

\begin{tabular}{cc}
\hline $\begin{array}{c}\text { Percentage of Waste Paper } \\
\text { Adhesives }\end{array}$ & \% Solid carbon \\
\hline $7 \%$ & 50,54 \\
$7,50 \%$ & 50,17 \\
$8 \%$ & 50,03 \\
$8,50 \%$ & 49,75 \\
$9 \%$ & 49,05 \\
$9,50 \%$ & 48,12 \\
$10 \%$ & 45,38 \\
\hline
\end{tabular}

As can be seen in Table 1 the effect composition of the waste paper adhesives on solid carbon content decreases with each increase in the adhesive composition. The highest solid carbon content is at $7 \%$ adhesive composition while the lowest solid carbon content is at $10 \%$ composition. This is influenced by the value of water content, ash content and levels of the briquette's flying substances. The lower the value of water content, ash content and briquette content, the higher the value of solid carbon content obtained. This is in accordance with, the presence of carbon content bound in charcoal briquettes is influenced by the value of ash content and levels of evaporating substances.

The calorific value determines the quality of the briquettes. The higher the heating value of the briquettes, the better the quality of the briquettes produced. The heating value is influenced 
by water content and ash content of briquettes. The higher the water content and ash content of the briquettes, the lower the heating value of the briquettes produced [12].

It can be seen in figure 4 that the lowest calorific value of $5573 \mathrm{cal} / \mathrm{gr}$ is found in the $10 \%$ adhesive composition, while the highest value is $5888 \mathrm{cal} / \mathrm{g}$ in the $7 \%$ adhesive composition. This proves that the lower the value of water content, ash content and levels of flying substances, the higher the heating value obtained. Other than that, the results of the data obtained also prove that the value of solid carbon content is directly proportional to the heating value [13]. The higher the value of solid carbon content, the higher the heat value obtained. The calorific value obtained in this study is around $5500-5900 \mathrm{cal} / \mathrm{gr}$.

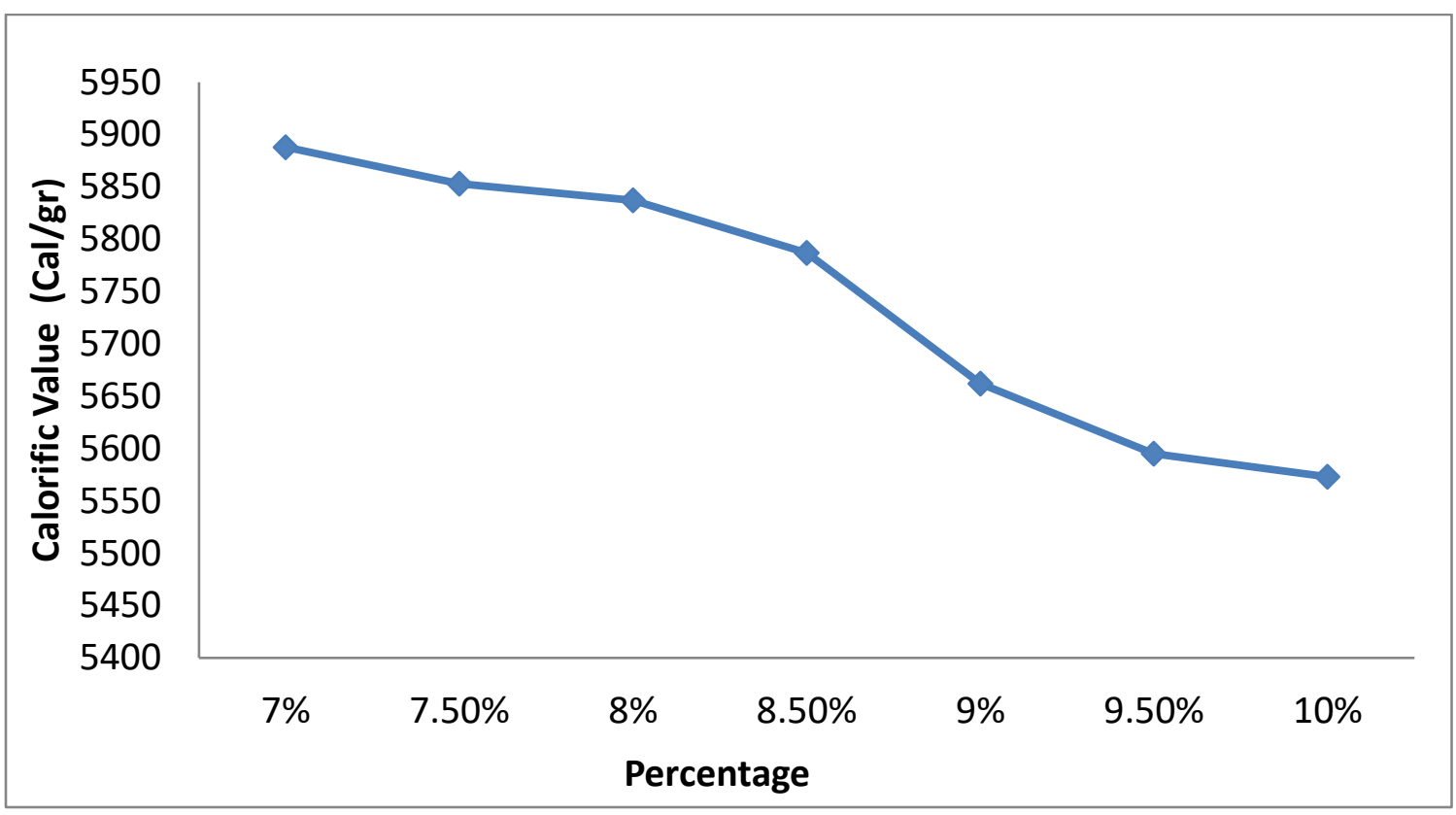

Fig. 4. The effect weight percentages of Waste Paper Adhesives to calorific value.

\section{CONCLUSION}

The sum of the discussion of this result are:

1. The optimal composition of waste adhesive in making briquettes made from cassava peel is $7 \%$. Because in this composition, briquettes get a calorific value of $5888 \mathrm{cal} / \mathrm{gr}$ and have a low water content, ash content and levels of flying substances.

2. Based on the results of tests conducted, the higher the composition of the adhesive used, the lower the quality of the briquettes.

\section{ACKNOWLEDGEMENT}

Thank to Universitas Sriwijaya to facilities this research.

\section{REFERENCES}

[1] Regulation of The Minister of Energy And Mineral Resources of The Republic of Indonesia. Indonesia, 2019.

[2] T. Assistance, U. Ausaid, I. Market, and D. Indonesia, "Introducing Market Development Indonesia ( IMDI ) Sector Report Cassava in East Java , \& NTT," 2015.

[3] CABI, "Datasheet Report forManihot esculenta (cassava)." [Online]. Available: https://www.cabi.org/isc/datasheet/32401. [Accessed: 11-Sep-2020]. 
[4] Z. Helwani et al., "Alternative briquette material made from palm stem biomass mediated by glycerol crude of biodiesel byproducts as a natural adhesive," Processes, vol. 8, no. 7, 2020.

[5] M. Mahidin, A. Gani, and K. Khairil, "Physical Characterization and Desulfurization of Biobriquette Using Calcium-Based Adsorbent," Makara J. Technol., vol. 15, no. 2, p. 178, 2013.

[6] V. D. Pratiwi, "Effect of Burning Temperature on The Quality of Alternatife Bio-energy from Coffee Waste," ELKOMIKA J. Tek. Energi Elektr. Tek. Telekomun. Tek. Elektron., vol. 8, no. 3, p. 615, 2020 .

[7] C. R. Lohri, H. M. Rajabu, D. J. Sweeney, and C. Zurbrügg, "Char fuel production in developing countries - A review of urban biowaste carbonization," Renew. Sustain. Energy Rev., vol. 59, pp. 1514-1530, 2016.

[8] O. A. Oyelaran, F. M. Sani, O. M. Sanusi, O. Balogun, and A. O. Fagbemigun, "Energy Potentials of Briquette Produced from Tannery Solid Waste," Makara J. Technol., vol. 21, no. 3, p. 122, 2018.

[9] L. Ifa et al., "Production of bio-briquette from biochar derived from pyrolysis of cashew nut waste," Ecol. Environ. Conserv., vol. 25, no. September Suppl. Issue, pp. S125-S131, 2019.

[10] Sunardi, Djuanda, and M. A. S. Mandra, "Characteristics of charcoal briquettes from agricultural waste with compaction pressure and particle size variation as alternative fuel," Int. Energy J., vol. 19, no. 3, pp. 139-147, 2019.

[11] C. Thassana and W. Nuleg, "Effect of carbon black on thermal properties of charcoal and salacca leafstalk briquettes," AIP Conf. Proc., vol. 1868, 2017.

[12] H. A. Ajimotokan, A. O. Ehindero, K. S. Ajao, A. A. Adeleke, P. P. Ikubanni, and Y. L. Shuaib-Babata, "Combustion characteristics of fuel briquettes made from charcoal particles and sawdust agglomerates," Sci. African, vol. 6, 2019.

[13] A. Demirbaş and A. H. Demirbaş, "Estimating the calorific values of lignocellulosic fuels," Energy Explor. Exploit., vol. 22, no. 2, pp. 135-143, 2004. 